\title{
Perbandingan prevalensi katarak senilis di daerah pantai dengan di daerah pegunungan
}

\author{
${ }^{1}$ Grace Rumerung \\ ${ }^{2}$ Laya M. Rares \\ ${ }^{2}$ J. S. M. Saerang \\ ${ }^{1}$ Kandidat Skripsi Fakultas Kedokteran Universitas Sam Ratulangi Manado \\ ${ }^{2}$ Bagian Ilmu Kesehatan Mata BLU RSUP Prof. Dr. R. D. Kandou Manado \\ Email: grace.rumerung17@yahoo.com
}

\begin{abstract}
Senile cataract is the most common form of cataract in old age, especially over 50 years old. Besides age, environment and geographic status can influence the occurence and development of senile cataract. This study aimed to compare the prevalence of cataract between patients living in coastal areas and in mountainous areas. This was a descriptive analytical study with a cross sectional design using data of the medical record. The results showed that the total samples were 66 patients; 55 patients (88.3\%) living in mountainous areas and 11 patients (16.7\%) in coastal areas. The Mann-Whitney U test showed a $P$ value of 1.000 . Conclusion: There was no significant difference in senile cataract prevalence between patients living in coastal areas and those living in mountainous areas.
\end{abstract}

Keywords: senile cataract, coastal areas, mountain areas

\begin{abstract}
Abstrak: Katarak senilis merupakan bentuk katarak yang paling sering didapatkan pada usia tua, umumnya setelah usia 50 tahun ke atas. Selain faktor usia, lingkungan, dan tempat tinggal/geografis dapat memengaruhi terjadinya dan kecepatan perkembangan katarak senilis. Penelitian ini bertujuan untuk mengetahui perbandingan prevalensi penderita katarak senilis di daerah pantai dan di daerah pegunungan. Jenis penelitian ini deskriptif analitik dengan desain potong lintang menggunakan data rekam medik. Hasil penelitian memperlihatkan total sampel sebanyak 66 orang. Sebanyak 55 orang $(83,3 \%)$ berasal dari daerah pegunungan dan sebanyak 11 orang $(16,7 \%)$ dari daerah pantai. Hasil Mann-Whitney U Test menunjukkan nilai signifikansi $P=1,000$. Simpulan: Tidak terdapat perbedaan bermakna dalam prevalensi katarak senilis di daerah pantai dan di daerah pegunungan.
\end{abstract}

Kata kunci: katarak senilis, daerah pantai, daerah pegunungan

Mata merupakan organ yang paling berguna dan bernilai tinggi karena sekitar $80 \%$ pengetahuan yang diperoleh masuk melalui organ penglihatan, yaitu mata. Mata juga merupakan jendela jiwa dan jendela kesehatan tubuh kita karena mata merupakan satu-satunya organ yang pembuluh darahnya dapat dilihat secara langsung. Mata berperan sangat penting bagi kehidupan manusia dan merupakan salah satu organ vital yang cukup sensitif dan rentan terhadap berbagai gangguan luar. Salah satu gangguan paling umum pada mata ialah katarak. ${ }^{1}$

Katarak dalam bahasa Yunani disebut kattarhakies, bahasa Inggris cataract, dan bahasa Latin cataracta) yang berarti air terjun. Dalam bahasa Indonesia katarak disebut bular dimana penglihatan tertutup seperti air terjun akibat lensa yang keruh. Pada katarak terjadi kekeruhan pada serabut atau bahan lensa di dalam kapsul lensa. Jadi katarak merupakan salah satu keadaan patologik lensa dimana lensa 
menjadi keruh akibat hidrasi cairan lensa, atau denaturasi protein lensa. Kekeruhan ini terjadi akibat gangguan metabolisme normal lensa yang dapat timbul pada usia tertentu. ${ }^{2}$

Katarak disebabkan oleh beberapa faktor seperti fisik, kimia, penyakit predisposisi, genetik, gangguan perkembangan, infeksi virus dimasa pertumbuhan janin, dan usia. Berdasarkan usia katarak dapat diklasifikasikan atas: katarak kongenital, yaitu katarak yang sudah terlihat pada usia di bawah 1 tahun; katarak juvenil yaitu katarak yang terjadi sesudah usia 1 tahun; dan katarak senilis yang disebabkan karena usia tua. Pada keadaan ini umumnya katarak timbul pada saat usia 50 tahun keatas. Katarak senilis dibagi dalam empat tingkatan, yaitu: insipen, imatur, matur, dan hipermatur. ${ }^{2}$

Katarak senilis sampai sejauh ini merupakan bentuk katarak yang paling sering didapatkan, yaitu sekitar 90\% dari insiden katarak seluruhnya. Keadaan ini merupakan salah satu penyebab kebutaan terbesar di dunia saat ini. ${ }^{3}$

Berbagai studi potong lintang melaporkan prevalensi katarak pada individu berusia 65-74 tahun sebanyak $50 \%$, dan prevalensi ini meningkat hingga $70 \%$ pada individu berusia di atas 75 tahun. ${ }^{4}$ The Beaver Dam Eye Study juga melaporkan bahwa sekitar 38,8\% laki-laki dan $45,9 \%$ perempuan yang berusia lebih dari 74 tahun menderita katarak. ${ }^{5}$

Selain faktor usia, lingkungan dan tempat tinggal/geografis merupakan beberapa faktor yang memengaruhi terjadinya dan kecepatan perkembangan katarak senilis. ${ }^{6}$ Dewasa ini prevalensi penyakit katarak hampir tersebar merata di seluruh Indonesia, baik yang berada di daerah perkotaan maupun di daerah-daerah terpencil. ${ }^{7}$

Penelitian ini bertujuan untuk mengetahui perbandingan prevalensi penderita katarak senilis di daerah pantai dan di daerah pegunungan.

\section{METODE PENELITIAN}

Penelitian ini dilakukan pada bulan
Oktober 2014 - Desember 2014 di RSU Bethesda GMIM Tomohon dan RS Kalooran GMIM Amurang. Jenis penelitian yang dilakukan ialah deskriptif analitik dengan desain potong lintang dan menggunakan data rekam medik. Subjek penelitian ini ialah semua data rekam medik pasien katarak senilis periode Juli 2013-Juli 2014 di RS Kalooran GMIM Amurang dan RSU Bethesda GMIM Tomohon. Populasi penelitian ini ialah pasien katarak senilis yang tinggal di daerah pantai dan di daerah pegunungan. Sampel untuk pasien katarak senilis di daerah pantai diambil dari data rekam medik di RS Kalooran GMIM Amurang sedangkan untuk daerah pegunungan diambil dari data rekam medik RSU Bethesda GMIM Tomohon.

Data yang diperoleh dikelompokkan berdasarkan variabel penelitian dan dihitung dalam bentuk distribusi frekuensi dan statistik.

\section{HASIL PENELITIAN}

Tabel 1 dan Gambar 1 menunjukkan bahwa pasien katarak senilis di daerah pegunungan lebih banyak yaitu 55 orang $(83,3 \%)$ dari pada di daerah pantai sebanyak 11 orang $(16,7 \%)$.

Tabel 1. Distribusi Berdasarkan Lokasi Tempat Tinggal

\begin{tabular}{lcc}
\hline \multicolumn{1}{c}{ Tempat Tinggal } & Frekuensi & $\%$ \\
\hline Daerah & 55 & 83,3 \\
Pegunungan & & \\
Daerah Pantai & 11 & 16,7 \\
Total & 66 & 100,0 \\
\hline
\end{tabular}

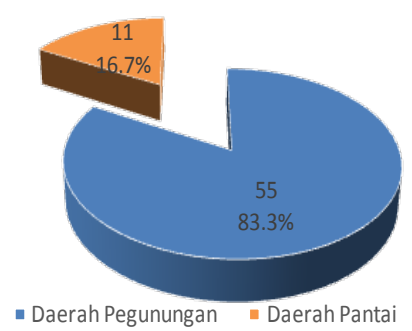

Gambar 1. Distribusi pasien katarak Berdasarkan Lokasi Tempat Tinggal 
Tabel 2 memperlihatkan uji statistik yang digunakan yaitu Mann- Whitney U Test oleh karena data tidak terdistribusi secara normal (nonparametrik data). Hasil uji statistik menunjukkan nilai signifikansi $P$ sebesar $1,000(>0,05)$ yang menunjukkan tidak terdapat perbedaan status katarak senilis di daerah pantai dan di daerah pegunungan.

Tabel 2. Hasil Analisis Statistik Perbandingan Prevalensi Penderita Katarak Senilis di Daerah Pantai dan di Daerah Pegunungan

\begin{tabular}{cc}
\hline Analisis & Value \\
\hline Mann-Whitney U & 302,500 \\
Z & 0,000 \\
Sig. & 1,000 \\
\hline
\end{tabular}

\section{BAHASAN}

Hasil pengumpulan data melalui data sekunder Rekam Medik mendapatkan bahwa sebagian besar sampel penelitian berasal dari daerah pegunungan yaitu sebanyak 55 orang $(83,3 \%)$ sedangkan dari daerah pantai sebanyak 11 orang (16,7\%). Selain itu, usia merupakan penyebab yang umum. Seiring dengan bertambahnya usia, protein di dalam lensa mata mengalami denaturasi dan degradasi. Proses ini akan dipercepat lagi oleh adanya penyakit diabetes dan hipertensi, dan diperparah oleh faktor lingkungan yang mengandung banyak polutan, radiasi, serta sinar UV. Semua itu mempunyai efek akumulasi menjadi katarak. Penelitian oleh Hutasoit ${ }^{8}$ di daerah pegunungan (Tapanuli Selatan) diperoleh data bahwa sebagian besar penderita kebutaan katarak ialah petani; keadaan ini dimungkinkan oleh pekerjaan dengan paparan matahari lebih banyak. Di satu pihak penelitian oleh Wahyudi et al. ${ }^{9}$ tentang hubungan pekerjaan tempat tinggal dengan tingkat kematangan katarak, diperoleh hasil bahwa persentase tertinggi penderita katarak senilis ialah pekerja lapangan dan dataran rendah sebanyak $61 \%$.

Paparan sinar ultraviolet meningkatkan risiko terkena katarak, terutama jika mata tanpa pelindung terpapar sinar matahari cukup lama. ${ }^{9}$ Para penderita katarak kebanyakan menyebar di daerah pesisir karena terpapar sinar matahari berlebihan dan daerah terpencil karena akses terhadap layanan kesehatan kurang, terutama di wilayah Timur Indonesia yang kondisi fasilitas kesehatan kurang memadai. Kondisi ini menyebabkan kesadaran dan kemampuan untuk mencegah maupun mengobati katarak masih terbatas. Setelah mengalami kebutaan barulah masyarakat mencari pengobatan sehingga jumlah kasus cenderung meningkat.

Hasil pengujian statistik diperoleh bahwa tidak terdapat perbedaan prevalensi katarak baik di daerah pegunungan dan daerah pantai $(P=1,000)$. Hal ini menunjukkan bahwa kejadian katarak sama-sama berpeluang terjadi di dataran tinggi dan dataran rendah. Setiap orang mempunyai kesempatan yang sama untuk menderita katarak, akan tetapi untuk mereka yang mempunyai riwayat keluarga katarak maka risiko akan lebih besar. Sebagian besar katarak terjadi karena proses degeneratif atau penuaan. Katarak dapat dicegah, antara lain dengan menjaga kadar gula darah selalu normal pada penderita diabetes melitus, senantiasa menjaga kesehatan mata, mengonsumsi makanan yang dapat melindungi kelainan degeneratif pada mata dan antioksidan seperti buah-buahan banyak yang mengandung vitamin $\mathrm{C}$, minyak sayuran, sayuran hijau, kacang-kacangan, kecambah, buncis, telur, hati, dan susu yang merupakan makanan dengan kandungan vitamin E, selenium dan tembaga yang tinggi. ${ }^{10}$

\section{SIMPULAN}

Berdasarkan hasil penelitian dan bahasan dapat disimpulkan bahwa walaupun prevalensi katarak yang diperoleh terbanyak di daerah pegunungan dibandingkan di daerah pantai tetapi secara statistik tidak bermakna. 
SARAN

Perlu adanya tindakan upaya pencegahan katarak senilis, berupa penyuluhan gizi (konsumsi protein cukup baik hewani maupun nabati), kesehatan kerja seperti menghindari bekerja langsung di bawah sinar matahari, dan penggunaan kacamata pelindung sinar matahari.

Perlu dilakukan penelitian lebih lanjut dengan memperhitungkan faktor-faktor lain yang dapat mepengaruhi prevalensi katarak senilis.

\section{DAFTAR PUSTAKA}

1. Wesscot AS. Visual Identity: Promoting and Protecting the Public Face of Organization. New York: M. E. Sharpe.Inc., 2009.

2. Ilyas S. Penglihatan turun perlahan tanpa mata merah. Ilmu penyakit mata (3rd ed). Jakarta: Balai penerbit FKUI, 2007; p. 200-11.

3. Ocampo VVD, Foster S, Talavera F, Rowsey JJ, Sheppard JD. Senile cataract. 15 September 2005. Available from:

http://www.emedicine.com/oph/topic49 .htm.

4. Vaughan DG, Asbury T, Riordan $\mathbf{P}$. Oftalmologi Umum. Jakarta: Widya Medika, 2000; p. 175-7.

5. Nugraha SV. Karakterististik Penderita Katarak Balai Kesehatan Mata Masyarakat Makassar. 2010. p. 16. Available http://repository.unhas.ac.id:4001/digili b/files/disk1/437/--vindynugra-218031-skripsi-\%29.pdf.

6. Wahyudi D, Rinayati. 2013. Hubungan Kebiasaan Merokok Konsumsi Vitamin E dengan Tingkat Kematangan Katarak Senilis. Prosiding Seminar Ilmiah Nasional Kesehatan. STIKES Widya Husada Semarang.

7. Fakultas Kedokteran Universitas Trisakti. 2009. Katarak Senilis. Makalah diskusi kelompok. Available from: http://musaahmad.blog.co.id

8. Hutasoit H. Prevalensi Kebutaan akibat Katarak di Kabupaten Tapanuli Selatan [Tesis Dokter Spesialis Mata]. Medan: Departemen Ilmu Kesehatan Mata FK USU; 2009.

9. Wahyudi D Rinayati, Erawati AD. Hubungan Pekerjaan Tempat Tinggal dengan Tingkat Kematangan Katarak. Prosiding SNST ke-4 tahun 2013. Semarang: Fakultas Teknik Universitas Wahid Hasyim; 2013.

10. Luthi T, WulanA, Hesti PR, Waya AW. Makalah Katarak dan Asuhan Keperawatan. Surakarta: Universitas Muhamadiyah; 2014. P. 11

11. Ismu PT. Faktor-Faktor Risiko Yang Berpengaruh Terhadap Kejadian Katarak Senilis. Studi Kasus di Kota Semarang dan Sekitarnya [Master Tesis]. Semarang: Program Pascasarjana Universitas Diponegoro, 2004. 